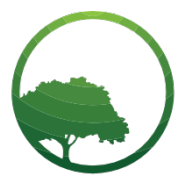

Research in Business \& Social Science

IJRBS VOL 8 NO 5 ISSN: 2147-4478

\title{
Role of family influence, gender, and entrepreneurial education on Indonesian vocational students becoming entrepreneurs
}

\author{
Maria Jacinta Arquisola ${ }^{a}$, Iseu Adywianti Muanar ${ }^{b}$, \\ ${ }^{a, b}$ School of Business, President University, Kota Jababeka, Cikarang Baru, Bekasi, West Java 17550, Indonesia
}

Crossref

\begin{tabular}{l} 
A R T I C L E I N F O \\
\hline Article history: \\
Received 12 July 19 \\
Received in revised form 29 July 19 \\
Accepted 02 August 19 \\
\hline Keywords: \\
Entrepreneurial Intention \\
Family Influence \\
Gender \\
Entrepreneurial Education \\
Vocational School \\
Indonesia \\
JEL Classification: \\
I23 \\
O15 \\
O35 \\
O53
\end{tabular}

\begin{abstract}
A B S T R A C T
The study analyzed whether family influence, gender, and entrepreneurial education would influence vocational students' desire to become entrepreneurs. A survey was conducted in 6 vocational schools in Tasikmalaya, West Java, involving 246 vocational students. Using multiple regression analysis, findings show that entrepreneurial education has the highest influence (57.5\%) shaping entrepreneurial intention among vocational students, while gender account for $30 \%$ influence on students' entrepreneurial intention. Male and female students believed that they must be given the same opportunities for entrepreneurship, yet there are feminine and masculine attributes that differentiate successful entrepreneurial plans between genders. Lastly, findings show that family background has the least influence (16\%) on entrepreneurial intentions. Respondents disclosed that there are many choices open to them aside from being entrepreneurs, and they would opt for this choice instead of following their parents. Nevertheless, they believe in family support through advice and access to capital. Implications for research, policy, and practice are discussed. This study has shown evidence that entrepreneurship can be a solution to Indonesia's high unemployment problem for young vocational students, but this entails better entrepreneurial education, the provision of gender-equal opportunities for males and female students, and enhanced family support for entrepreneurial ventures.
\end{abstract}

\section{Introduction}

Entrepreneurs play a significant role in a country’s development (Neequaye, et al., 2017). Entrepreneurial activities are instrumental in creating more productive income-generating activities, enhance innovation, business expansion and open job opportunities. Newlyelected second-term Indonesian President Joko Widodo announced that Indonesian markets are widely open for entrepreneurial ventures to local and domestic entities despite the fact that foreign countries look at the bullish state of Indonesian markets and are eager to invest (www.kominfo.go.id, 2017). Recognizing this importance, the Indonesian government launched many programs to spur entrepreneurial growth and increase the ratio of entrepreneurship activities, particularly for Indonesia youths (www.depkop.go.id, 2017).

This study makes a contribution to context-based research on factors influencing the entrepreneurial intentions of young vocational students in a rapidly-developing country like Indonesia. There are two justifications for this research. First, Indonesia's entrepreneurial base has been growing steadily from 1.6 percent to 3.1 percent. However, this increase is still considered small when compared to the country's 260 million population (BPS, 2016). Compared to other Asian countries, Indonesia does not fare well either; its neighbours have greater number of entrepreneurs like Malaysia (5\%), Thailand (4.5\%), and Singapore (7\%) (www.kominfo.go.id, 2017). Second, according to the Indonesian Central Bureau of Statistics (BPS) there is a high rate of unemployment among graduates from vocational schools totaling $8.92 \%$ of that population (See Figure 1). Some of the documented

\footnotetext{
* Corresponding author. Tel: +62-89109762 ORCID ID: 0000-0002-8370-9909

Peer review under responsibility of Bussecon International Academy.

(C) 2019 Bussecon International. Hosting by SSBFNET- Center for Strategic Studies in Business \& Finance. All rights reserved.

https://doi.org/10.20525/ijrbs.v8i5.309
} 
issues besetting vocational students are: a) lack of available regional and local jobs; b) skills qualification level does not match industry skills requirements; c) entrepreneurial knowledge is lacking.

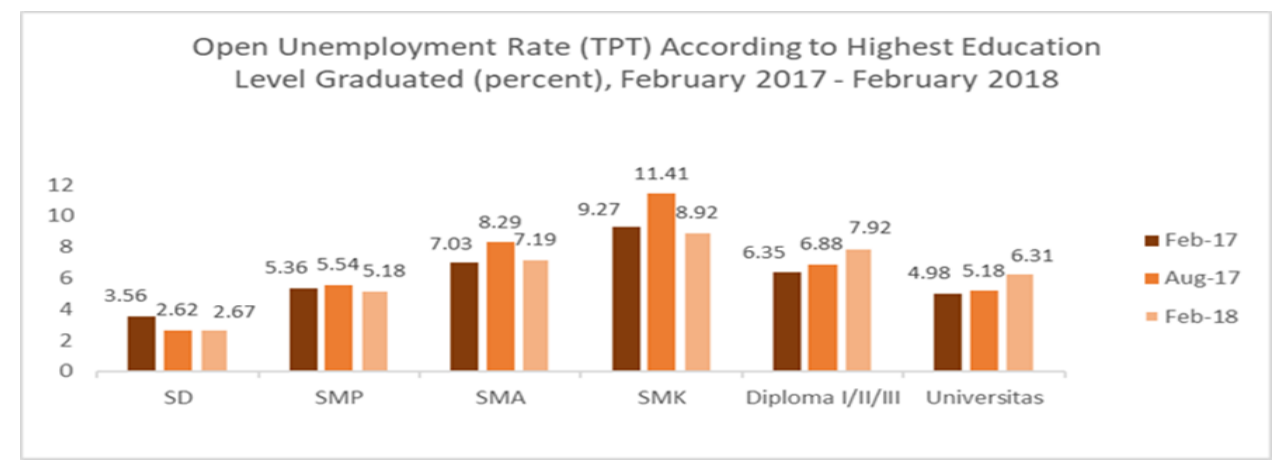

Source: Badan Pusat Statistic (BPS) Indonesia February 2018

Figure 1: Unemployment Rate According to Educational Background

Considering their low labor absorption due to these factors (Fatimah, 2018), alternatives proposed therefore were to motivate them to embark on entrepreneurial activities utilising local resources, and encouraging them to make full use of government-funded programs targeting and supporting small start-up ventures, for example, for example providing community-based micro credit, also known locally as Kredit Usaha Rakyat (KUR) that provide low interest loans to small business start-ups. Growing this base is therefore at the top of the country's development agenda (BPS, 2016; www.depkop.go.id, 2017) and the government is exerting effort to increase awareness of the valuable contribution of entrepreneurship program as a key driver of national economic growth. Therefore, encouraging young people to become entrepreneurs is immensely important to spur local and regional growth, as well as a significant solution to youth unemployment problems in Indonesia. While the Indonesian government has been relentless in its efforts to engage young people to become entrepreneurs, there has been limited research on what factors would influence them to choose this economic pathway. Previous research used organizational and individual factors as variables in the study of entrepreneurial intentions (see Lee, Wong, Foo, \& Leung, 2011; Neequaye, Dechun, Sholihah, \& Fynn, 2017), while other studies show that involvement in entrepreneurial activities may be driven by entrepreneurial education, entrepreneurial family background and the environment such as the inflence of family and friends (Shirokova, Osiyevskyy, \& Bogatyreva, 2015). Moreover, family background plays a huge role in shaping entrepreneurial intentions (Aldrich \& Cliff, 2003). Role modeling for a child to become an entrepreneur originates from the modelling shown by a parent who is an entrepreneur (Farrukh, Khan, Khan, Ramzani, \& Akeem, 2017), affecting the child's sense of entrepreneurial intention. Many studies have proposed that gender has an influence on behavioral intentions to be an entrepreneur (e.g. Gupta, Turban, Wasti, \& Sikdar, 2017; Nitu-Antonie, 2017; Shinnar, Hsu, \& Powell, 2014; Bergman, Rosenblatt, Erez, \& De-Haan, 2011). Entrepreneurship education is a key driver in encouraging entrepreneurship activities and job creation, especially when job availability is limited (Shinnar, Hsu, \& Powell, 2014).

These prevailing studies lend credence to the important factors influencing entrepreneurial motivations but in the case of young Indonesian vocational students, there is hardly any study conducted on local-based entrepreneurship formation among young vocational students in Indonesia using the variables of entrepreneurial education, gender, and family background. Based on these premises, this research aims to answer the question: Would family influence, gender, and entrepreneurial education encourage entrepreneurial intentions among vocational students in Indonesia? In the ensuing discussion, the article describes the research setting, followed by a review of the literature, then the research methodology taken to collect and analyze the data, followed by empirical findings and discussions. The paper concludes with implications to policy and practice.

\section{Literature Review}

\section{Family influence}

The role of the family on entrepreneurial attitude and intentions has been identified, especially the support of family members in creating positive influence to build desirability to start a business (Pant (2015). Chlosta, Patzell, Sabine, and Dorman (2012) argued that an entrepreneurial family can direct children to develop social learning skills and imbibe their values of hard work and independence. To become a self-employed individual appears from the way parents give informal introduction to business models. The extent of family exposure to entrepreneurial modelling influences a family member's preference to become an entrepreneur (Wyrwich, 2015). For example, children are argued to be thinking of self-employment and entrepreneurship because the family models it as a source of future occupation (Pant, 2015). In addition, research reveals that having a parent or family member who is self-employed or is an entrepreneur significantly raises the tendency of individuals to pursue the same path of career path (Bignotti \& Roux, 2018). Those families with business backgrounds have the skills and abilities for an entrepreneurial career (Konig, Kammelander, \& Enders, 2013). Family members provide the inspiration and alternative preference (Dyer, 2006). Parental role models influence individual career decisions because children are exposed to their parent's behaviors where they are likely to imitate them (Schmitt-Rodermund \& Vondracek, 2002). Individuals who have strong relationships with family members might obtain 
encouragement and advice to pursue self-employment (Sequeira, Mueller, \& McGee, 2007). Therefore, a strong social network relationship such as the family plays a vital role in influencing individuals' intention towards creating a new venture (Aldrich \& Cliff, 2003). However, research also shows that there are parents who would not let their children become entrepreneurs because their own aspiration was not achieved; they prefer their children to be employees instead (Zellweger, et al, 2010). Young adults recognize this parental preference and hence have opened their minds to other possibilities which induce creative, innovative and critical mindsets (Zhao \& Seibert, 2006). According to Bandura (1992) the presence of role models can lead individuals to try similar behavior, or even create new behavior from the observation of role models. The first hypothesis of this research is therefore:

H1: Family influence affects the entrepreneurial intentions of vocational students in Tasikmalaya, West Java.

\section{Gender}

Males and females have their own specific concerns and interest, and this could apply to their career choice to become entrepreneurs (Sánchez, \& Licciardello, 2012). For example, research has shown that men show strong interest and higher risk taking to become entrepreneurs than women (Joensuu-Salo, Varamäki, \& Viljamaa, 2015). Langowitz and Minniti (2007) argue women significantly display lower risk-taking tendency and entrepreneurial intentions than men. The difference in interest to entrepreneurial activity emanates from the socially and culturally contracted gender roles of females (Yukongdi \& Lopa, 2017). An earlier study (see Bandura, 1992) suggests that when compared to men, women limit their career aspirations because they believe they have no capabilities and skills for such ventures. This an unfortunate case as study shows that females who take on ventures that demand assertiveness contribute highly to the performance of the firm (Arquisola, Shella, \& Hutabarat, 2018). Entrepreneurial role models influence more women than men; thus, it is argued that to enhance attractiveness and desirability to become entrepreneurs, women need more entrepreneurial role models (Jennings \& McDougald, 2007). Additionally, women are inclined to be more process oriented that affect women's confidence in their entrepreneurial abilities (Karimi, Biemans, Lans, Chizari, \& Mulder, 2014). The core essential qualities of business leaders are that they are independent, aggressive, risk-takers, have autonomy, and being courageous. Most of these characteristics are found within men (Gupta, Turban, Wasti, \& Sikdar, 2017). These are male gender stereotypes (Shinnar, Hsu, \& Powell, 2014) that pervade women's consciousness: the environment is less favorable for them because men have the masculine advantage (Langowitz \& Minniti, 2007). These negative stereotypes affect women's decisions as they are expected to follow prevailing gender norms (Welter, Smallbone, Isakova, \& Aculai, 2007). This means that they are expected to embrace motherhood and being a support to the husband and not as main bread winner (Arquisola, Shella, \& Hutabarat, 2018).

Similarly, Díaz-García and Jiménez-Moreno (2010) argue that women have lower self-efficacy and confidence to begin entrepreneurial activities. Feminine and masculine attributes of gender roles on women and men affect task distribution (Díaz-García \& Jiménez-Moreno, 2010). For instance, due to the perceived masculine character, men are likely to have higher intentions to create a firm; however, in managing a firm, men need feminine attributes because entrepreneurial activities are process-orientated and need meticulous behaviors found in women. The opposite case happens for women: when they become leaders, they need masculine attributes in a leader position that may run counter to expected gender norms, known as a double bind situation confronting females with agentic abilities (Arquisola, 2017). The second hypothesis of this research is therefore:

H2: Gender influences the entrepreneurial intentions of vocational students in Tasikmalaya, West Java.

\section{Entrepreneurship education}

In developing economies like Indonesia, the significance of entrepreneurial education has been highlighted as a fundamental strategy in developing entrepreneurial skills in order to 'facilitate employability of graduates and become job creators' similar to what is being done in African nations like Ethiopia (Tarekegne \& Galeneh, 2019, p. 62). Entrepreneurial education offers knowledge, skills, attitude and intention that are needed for molding entrepreneurship character (Farrukh, Khan, Khan, Ramzani, \& Akeem, 2017; Cox, Mueller, \& Moss, 2002). Entrepreneurship education must begin at vocational schools and needs focusing in higher education; it must be incorporated into the business and non-business disciplines of engineering and science where students are not sufficiently educated in the knowledge and skills required for start-ups (Kok, 2004 cited in Tarekegne \& Galeneh, 2019, p.70). For example, by doing a market analysis or writing a business plan as a component of an entrepreneurship course assignment, students are likely to develop skills and confidence in their ability to understand business landscape factors likely to affect a start - up venture. Similarly, attending seminars of entrepreneurship influencers enables them to learn techniques and strategies for a successful entrepreneurial path. As Bergman, Rosenblatt, Erez, \& De-Haan (2011) argue, a person's entrepreneurship intention is driven by social persuasion, feedback, and discussion forum from people with real-life, relatable experience. Entrepreneurship education gives students positive impact in terms of the desirability to become entrepreneurs. A study by Foster (2018) indicates that if an entrepreneur wants to succeed in the creative industry, for example, he/she needs important competencies like relationship competencies, opportunity competencies, strategic competencies, human competencies and personal strength competencies - these are skill sets that a rigorous entrepreneurial education can provide, as long as these are also integrated into the vocational schools entrepreneurship curriculum.

Based on Vaizler's (2011) research, factors influencing students' mindset about entrepreneur intention is inspired by the entrepreneurial courses they receive (see also Soutaris, Zerbinati, \& Al-Laham, 2007; Lespita, Heblich, Breugst, \& Patzelt, 2012). Moreover, research shows that the duration of entrepreneurial education can create positive impact for entrepreneur's self-efficacy; the longer the exposure to such courses, the more exposed students become, informing their mindsets (Shinnar, Hsu, \& Powell, 2014). 
Furthermore, entrepreneurial self-efficacy is associated with entrepreneurial education which develops these four determinants: enactive mastery, vicarious experience, verbal persuasion, and emotional arousal. Students who enroll in entrepreneurship courses are exposed to these four self-efficacy models. For instance, talking to successful entrepreneurs help students understand coping strategies necessary for business leading to greater success and increase entrepreneurial self-efficacy (Jun, Qian, Miao, \& James, 2014). The duration of entrepreneurship education, the number of times spent by students to learn and their absorption of study materials have been shown to impact entrepreneurship intention. The main difference is absorption, understanding, and memorized materials (Chiang \& Tomimatsu, 2011). While Minniti and Bygrave (2001) argue that entrepreneurship intention will be stronger if the relationship with the entrepreneurial education results in creating business ventures, business plans, and learning by doing experience. The third hypothesis of this research is therefore:

H3: Entrepreneurship education influences the entrepreneurial intentions of vocational students in Tasikmalaya, West Java

\section{Research and Methodology}

\section{Research Setting}

The city of Tasikmalaya was chosen as research site for this study. Tasikmalaya is one of the cities in the province of West Java, and considered the largest city in the East Priangan region. Tasikmalaya is close to Bandung, the capital of West Java. The current governor Ridwan Kamil continues to be committed to improve the welfare of micro, small and medium enterprises. For example, he launched the Little Bandung program to showcase Indonesia's finest local creative products such as the Batik textile, Halal - certified fashion garments and accessories, and various other souvenirs that the region is known for like bamboo-based furniture, leather bags, and floor mats made from pandan leaves (Pasha, 2018). Collaborations with big e-commerce platforms like Bukalapak have opened opportunities for local entrepreneurs to venture into the online e-retail markets that enabled West Java products to be sold online. Many of these creative products come from Tasikmalaya (Khumaini, 2018). For example, in the art of embroidery in Kawalu, Tasikmalaya, artisans there have vouched that the business was passed down by inheritance, where many generations down the line continue this art as a hereditary business. It is no wonder that almost every household in the area continue to make this embroidery (Inibaru.id, 2018). However even with this close proximity to Bandung, Tasikmalaya suffers from high unemployment rate among the youths. Data from BPS 2018 shows unemployment in productive age in Tasikmalaya reached 6.8\% in 2018, from 5.5\% in 2017, and increase of $1.3 \%$ in 2018 . The high unemployment rate is dominated by vocational high school and senior high school graduates. This situation occurs because the increase in the unemployment rate is not accompanied by an increase in employment absorption rates (Sulaksono, 2018).

\section{Profile of respondents}

The total number of respondents were 246 vocational students from 6 vocational high schools in Tasikmalaya, West Java, Indonesia. In terms of gender, majority of respondents $(n=211,86$ percent) were females while the rest were males $(n=35,14 \%)$. In terms of age, majority of respondents were aged between 16 years old $(n=209,85 \%)$, while the rest are 17 years old $(n=37,15 \%)$. In terms of family background, half of respondents $(n=138,56 \%)$ came from families who had a business background, and the rest $(n=108$, 44\%) did not come from family business background.

\section{Data collection}

A 5- point Likert scale survey questionnaire was used to collect data on site. Random sampling was used to take advantage of the presence of students who were scheduled to take the final semester exams. Prior to data collection, the questionnaires were tested for reliability and validity on 30 students. The instrument was found to reliable with $\alpha=0.822$ (reliable if $\alpha$ is between $>0.70-0.90$ ). Then 250 questionnaires were distributed to 6 vocational schools. Response rate was 98 percent where 246 respondents filled up the questionnaire. The strategy employed for data collection involved the researchers asking permission from the school administrators to conduct the survey. The researchers also requested the help of a local contact who was actually teaching at the vocational schools. This local contact was from a local university who teaches entrepreneurship in vocational schools. This local contact also assisted in distributing the questionnaires to the class. The distribution had to be timed after the students have finished their school semester exams. The researchers therefore obtained the advantage in which students had enough free time to fill out this questionnaire and can represent their answers well.

\section{Data analysis}

Due to the context-based exploratory nature of this study descriptive statistics using the mean and standard deviation were used to analyze which of the three operant dimensions (variables) occupied the central place compared to other dimensions, without intending to accept generally accepted conclusions or generalizations (Arikunto, 2016). Multiple regression analysis was used to make predictions whether the dependent variables (Sugiyono, 2014). Coefficient of determination (R2 Test) was used as a technique to see how weak or strong the influence is of independent variables on the dependent variable. This method can show the strength of independent variables has relationship with dependent variable.

The hypotheses were tested using a) T-Test or partial regression to determine how far the influence of one independent variable (Family influence, gender, entrepreneurial education) individually in explaining the dependent variable (entrepreneurial intentions); 
and b) F-Test or ANOVA to identify if there is the simultaneous influence of all independent variables toward dependent variable or not (if $\mathrm{F}$ value is less than 0.05 . In addition, if $\mathrm{F}$ value $>\mathrm{F}$ table, Ho will be rejected, Ha will be accepted and vice versa).

\section{Empirical data and analysis}

Forty - five percent $(45 \%)$ of respondents agreed that their family will give them support, advice, and capital if they become entrepreneurs. Yet despite this, less than a quarter (23\%) said they are neutral about the motivation to become entrepreneurs because their family has a business, or their father or mother is an entrepreneur.

In terms of gender, analysis shows that both male and female respondents believe that males and females should be given the same opportunity to be entrepreneurs, however it is the female respondents who have the loudest voice in this regard (average 43.6 percent), while only an average 22 percent of males say they agree to the statement. Female respondents' desirability to have a business is higher (54 percent) than males (52\%). However, in terms of readiness to start their business, both male and female respondents show readiness (33 percent). In terms of their belief whether males have greater potential to be entrepreneurs, few female respondents believe so (15 percent), while more males believe they have greater potential to be entrepreneurs ( 49 percent). On the belief that females have greater potential to be entrepreneurs, 25 percent of female respondents believe so, while in the case of male respondents, very few believe so (8.04\%). More importantly, both male and female respondents agree that they lack the practical skills and know how to start a firm.

In terms of entrepreneurial education, 76 percent of respondents believe in the high importance of teaching entrepreneurial subjects in all vocational majors in the country. Sixty-six percent of respondents believe that if entrepreneurial education is available, it means that their school supports their desire to be entrepreneurs. The respondents agreed that entrepreneurship subjects are important for students especially to give them motivation and insight about entrepreneurship. Entrepreneurship subjects in their school would help students increase the interest and encourage them to venture into entrepreneurship activities. More than 55 percent of respondents, both male and females, said that they are ready to become entrepreneurs - it is part of their future goals (71.5\%). They believe that being an entrepreneur bring many advantages to their lives (50\%), ensuring greater satisfaction in their future lives $(63.8 \%)$.

Based on the T-Test result in Table 1, it can be shown that all 3 variables have significant influence toward entrepreneurial intentions. On family influence, the result of T-test shows 2.871 (greater than T table 1.660). Therefore, the hypothesis on family influence is accepted. On gender, the result of $\mathrm{T}$-test shows 4.732 (greater than $\mathrm{T}$ table 1.660). Therefore, the hypothesis on gender is accepted. On entrepreneurial education, the T-test results show 8.533 (greater than T table 1.660). Therefore, hypothesis on entrepreneurial education is accepted. From these results, the family has the least influence on entrepreneurial intention while having access to entrepreneurial education has the highest influence.

Table 1: Multiple regression analysis- coefficient

\begin{tabular}{|c|c|c|c|c|c|c|c|}
\hline \multirow[t]{2}{*}{ Model } & \multicolumn{2}{|c|}{$\begin{array}{l}\text { Unstandardized } \\
\text { Coefficients }\end{array}$} & \multirow{2}{*}{$\begin{array}{l}\text { Standardized } \\
\text { Coefficients } \\
\text { Beta }\end{array}$} & \multirow[t]{2}{*}{$\mathrm{t}$} & \multirow[t]{2}{*}{ Sig. } & \multicolumn{2}{|c|}{ Collinearity Statistics } \\
\hline & $\mathrm{B}$ & Std. Error & & & & Tolerance & VIF \\
\hline (Constant) & 3.105 & 1.623 & & 1.913 & .057 & & \\
\hline Total_FI & .161 & .056 & .152 & 2.871 & .004 & .685 & 1.459 \\
\hline Total_G & .300 & .063 & .265 & 4.732 & .000 & .617 & 1.620 \\
\hline Total_EE & .575 & .067 & .455 & 8.533 & .000 & .680 & 1.471 \\
\hline
\end{tabular}

Source: SPSS 21.0 Analysis Output (2019)

The results in Table 2 show F-value is 91.814 which means greater than F-table 2.65 with a significance level of 0.000 , which is less than $\alpha(0.05)$. It means that family influence, gender, and entrepreneurial education simultaneously influence towards vocational students' entrepreneurial intention.

Table 2. ANOVA

\begin{tabular}{lllllll}
\hline Model & & Sum of Squares & df & Mean Square & F & Sig. \\
\hline & Regression & 2496.245 & 3 & 832.082 & 91.814 & $.000^{\mathrm{b}}$ \\
\cline { 2 - 7 } & Residual & 2193.169 & 242 & 9.063 & & \\
\cline { 2 - 7 } & & & & & & \\
\hline Total & 4689.415 & 245 & &
\end{tabular}

\footnotetext{
a. Dependent Variable: EIT

b. Predictors: (Constant), EET, FIT, GT

Source: SPSS 21.0 Analysis Output (2019)
} 
As shown on Table 3, the value of coefficient determination is 0.527 , which is a value between zero and one. This means that 52.7 $\%$ of entrepreneurial intentions of vocational students are influenced by the family, gender and entrepreneurial education, while the rest $(46.8 \%)$ can be explained by other variables that affect the entrepreneurial intentions but are not included in this research.

Table 3: Coefficient of Determination

\begin{tabular}{llllll}
\hline Model & R & R Square & Adjusted R Square & $\begin{array}{l}\text { Std. Error of the } \\
\text { Estimate }\end{array}$ & Durbin-Watson \\
\hline $\mathbf{1}$ & $.730^{\mathrm{a}}$ & .532 & .527 & 3.01043 & 1.976 \\
\hline
\end{tabular}

Source: SPSS 21.0 Analysis Output (2019)

\section{Findings and Implications}

\section{The influence of the family towards entrepreneurial intentions of vocational students}

Results show that family influence has significant influence towards entrepreneurial intentions of vocational students. These findings are corroborated by descriptive analysis showing that respondents believe their decision to choose a future career as an entrepreneur, where all the risks involved in creating a new business will be strongly supported by their families. They expect the support in the form of advice and capital to start their small business ventures. These findings confirm previous research (Shen, et.al., 2018) which emphasized that family support has a significant positive influence on perceived desires and the feasibility of starting a business for students. For example, those families with business background are likely inclined to have skills and abilities for an entrepreneurial career (Konig, et.al, 2013) which can be passed on to their children. For vocational high school students, their economic and emotional dependency on their families and their limited life experience might force them to find the support from their parents when considering career choice, especially entrepreneurship (Zellweger, Sieger, \& Halter, 2010).

However, respondents did not agree that because their family has a business, they will eventually become entrepreneurs themselves. Very few of them agreed that they will follow their parents (mother or father) to become entrepreneurs too. This finding disconfirms existing research (Farrukh, Khan, Khan, Ramzani, \& Akeem, 2017; Schmitt-Rodermund \& Vondracek, 2002) which suggested that parental modelling as entrepreneurs create a desire in their children to follow their footsteps. Therefore, the family does not significantly influence vocational students' intentions to become entrepreneurs because students have their own personal desire to pursue their own personal path other than being an entrepreneur. Furthermore, it can be argued that students' informal social network and access to social media technology are instrumental in making them look for other options to create new ventures other than being entrepreneurs like their parents (Aldrich \& Cliff, 2003). The results confirm arguments by Zhao and Seibert (2006) that young people have open-minded attitudes towards choice of career path, and will likely use these attitudes in selecting ventures suitable to them and which induce them to be creative, innovative, and critical to parental influence. Confirming Pan (2015), the choice of entrepreneurship and their parents' profession did not really influence students' intentions for an entrepreneurial career. In this study, the family has the least influence on entrepreneurial intentions of Indonesian vocational students.

\section{The influence of gender towards entrepreneurial intentions of vocational students}

The findings show that there are different beliefs between female and male students in entrepreneurial intentions. Gender has the second highest influence (30\%) to entrepreneurial intentions. Gender influences human personality and how that behavior is expressed (Joensuu-Salo, et.al., 2015). Data shows that male students have more confidence with their entrepreneurial ability than female students, confirming research by Langowitz \& Minniti (2007). On the other hand, female students have less - convincing opinions of their capability to start entrepreneurial activities. Male students in this study show higher confidence in starting a business, similar to findings by Díaz-García \& Jiménez-Moreno, (2010) arguing that men tend to think about creating a firm than being determined to do it. Moreover, both male and female students agreed that being entrepreneurs need to have feminine and masculine attributes to make the venture successful. This shows that the more a student feels he/she should pursue this path, the greater their intention or motivation to become one. This finding supports previous research (e.g. Sanchez \& Licciardello, 2012) attesting to the perception that males have higher self-efficacy in terms of starting a new business ventures than females while females have the desire to become one, however they are stifled by lack of self-efficacy or confidence in the ability to become successful future entrepreneurs.

The result of gender influence on entrepreneurial intentions need to be given attention by schools, social support, and government to provide female students with interventions that will boost their confidence with their ability to become entrepreneurs, as this study shows that they have less confidence about their entrepreneurial ability. Females have many choices to decide what actions to take that could enhance confidence in their entrepreneurial abilities (Karimi, et.al, 2014). They must capitalize on their inner higher desire for entrepreneurship. They could rely on family support or take up courses that will increase their skills. A preference for an entrepreneurial career influences the extent of support from family members (Wyrwich, 2015). This can be applied to females as well. Thus, it is important to consider family support when planning an entrepreneurial career. Female students can obtain encouragement, advice, or other forms of support to pursue self-employment career. In sum, students with entrepreneurial intentions 
must be directed or advised to pursue those actions that will influence their future goal to be entrepreneurs. In this study, it is clear that a generally gender-supportive climate in vocational schools in Tasikmalaya, West Java could drive that pursuit much clearer.

\section{The influence of entrepreneurial education towards entrepreneurial intentions of vocational students}

Findings show that entrepreneurial education enhances their entrepreneurial intentions through entrepreneurial courses given by their schools, enabling them to get knowledge and insights about entrepreneurship. Entrepreneurial education has the highest influence in this research at $57.5 \%$. The willingness to learn entrepreneurial subject is high among respondents. Students who have a lot of knowledge and learning about entrepreneurship will have greater entrepreneurial intentions (Vaizler, 2011). This finding corroborates earlier study (e.g. Jun, et.al.,2014) which argued that entrepreneurial intention is commonly inspired by entrepreneurial courses. Entrepreneurial education is significantly linked to entrepreneurial intentions consistent with previous research by Lee, Wong, Foo, \& Leung (2011) whose study showed that the important role of entrepreneurship education is to inspire students' inclination towards entrepreneurship. Entrepreneurial education provides the students with necessary soft skills about entrepreneurship (for example the spirit, mindset, attitudes and behavior of an entrepreneur), and the corresponding hard skills (financial planning, budgeting, marketing, and the use of e-commerce). Entrepreneurial education helps enhance their capability in managing their start- up businesses, and improve their attitude towards entrepreneurship, in turn, increasing entrepreneurial intentions (Lee, Wong, Foo, \& Leung, 2011).

\section{Implications for Policy and Future Research}

Future research could examine what types of entrepreneurial education courses or learning materials will be most beneficial and what types of teaching methods will work. The government can support vocational schools by proving educators with access to more updated teaching materials on entrepreneurship, and encouraging better institutional collaborations between vocational schools in so far as sharing educative entrepreneurial education and teaching methods.

In terms of policy, this study has major implications nation-wide. In many of the big Indonesian provinces, there are many informal education providers like the PKBM (Pusat Kegiatan Belajar Masyarakat - Center for Community-based Education) which can provide technical skills training in starting local creative ventures and small cottage industries. The schools can collaborate with PKBM to obtain more skills-based training because students are more eager to learn hard skills outside schools. PKBM supports the skills training with certification as well; therefore, vocational students not only obtain hands-on skills learning, they obtain formal certifications that they can use to apply for alternative employment in case they decide to pursue a non-entrepreneurial career. PKBM - related training can also enhance informal socialized access to confidence-building activities, adding value to improve their attitude and mindset such as entrepreneurial self-efficacy in females. Moreover, beyond training, future research could look into why female students have less confidence to be entrepreneurs, and what singular programs could increase their self-efficacy to be entrepreneurs. In this study, findings on female students' lack of self-efficacy is significant. Competencies proposed by Foster (2018) can be used as a guiding framework for further research, and geared towards both female and male students in order to bring into focus the reasons for the differences in entrepreneurial intentions between genders.

\section{Conclusions}

This study has drawn inspiration from the national government's agenda increasing the employment opportunities for young vocational students by promoting entrepreneurship activities as this cohort has the highest rate of unemployment region-wide and nation-wide. This study therefore has shown evidence that entrepreneurship can be a solution, but this entails better entrepreneurial education, the provision of gender equal opportunities for males and female students, and enhanced family support for entrepreneurial ventures. Findings from this study has contributed in raising awareness of the important factors necessary to increase entrepreneurial intentions among these young cohort, although the factor 'family influence' disproves our hypothesis that parental influence would have a significant influence on vocational students to become entrepreneurs following the footsteps of their parents. The Indonesian government must therefore focus attention on enhancing entrepreneurial education among vocational schools, provide them and their students with good quality educators who have teaching experience in teaching entrepreneurial subjects, and create more programs to broaden student's insights, knowledge, self-efficacy and intentions toward entrepreneurial activities.

Undertaking this study in one local area was a key limitation of this study, hindering nation-wide generalization, although other regions have similar problems. Another limitation was that the study did not cover examining educational research materials and delivery which are important for raising awareness. However, this could be addressed by further research as already emphasized.

\section{References}

Ajike, E., Goodluck, N., Hamed, A. Onyia, V. Kwarbai, J. (2015). Entrepreneurship Education and Entrepreneurial Intentions: The Role of Theory of Planned Behaviour. International Journal of Advanced Research in Social Engineering and Development Strategies, 3(1), 2-18

Aldrich, H. E., \& Cliff, J. E. (2003). The pervasive effects of family on entrepreneurship: Toward a family embeddedness perspective. Journal of Business Venturing, 18(5), 573-596. http://doi:10.1016/S0883-9026(03)00011-9

Arikunto. (2016). Prosedur Penelitian Suatu Pendekatan Praktik. Jakarta: Rineka Cipta. 
Arquisola, M.J., Shella, K. \& Hutabarat, E. (2018). How does board diversity affect the financial performance of commercial banks in Indonesia? An Inquiry. Jurnal Manajemen 12 (1), 62-73.

Arquisola, M.J. (2017). I see myself as climbing a mountain: Female leaders' constraints and sensemaking in Indonesian higher education. Proceedings of the DIES Conference: Female Leadership and Higher Education Management in Developing Countries, Bonn, Germany,28-30,June, 2017.

https://www.daad.de/medien/veranstaltungen/daad_gender_conference_proceedings_2017.pdf

Badan Pusat Statistic (BPS, 2018). Indikator pasar tenaga kerja Indonesia Februari 2018. Jakarta: Badan Pusat Statistics Publication no. 04120.1803. ISSN 2088-5679.

Bandura, A. (1992). Social cognitive theory: An agentic perspective. Asian Journal of Social Psychology, 2, 21-41. https://doi.org/10.1111/1467-839X.00024

Bergman, N., Rosenblatt, Z., Erez, M., \& De-Haan, U. (2011). Gender and the effect of entrepreneurship training program on entrepreneurial self-efficacy and entreprenurial knowledge gain. Entrepreneurship Small Business, 13(1), 38-54. https://doi: 10.1504/IJESB.2011.040415

Bignotti, A., \& le Roux, I. (2018). Discovering the entrepreneurial endowment of the youth. African Journal of Economic and Management Studies, 9 (1), 14-33. https://doi.org/10.1108/AJEMS-02-2016-0020

Brown, D., Brooks, L., \& Associates (Eds.). (1990). Career choice and development (2nd ed.). San Fransisco: Jossey-Bass. https://doi.org/10.1002/bdm.3960070307

Chiang CW., Tomimatsu K. (2011). Interaction design teaching method design. In: Jacko J.A. (eds). Human-Computer Interaction. Design and Development Approaches. HCI 2011. Lecture Notes in Computer Science, pp. 45-53. Berlin: Springer:

Chlosta, S., Patzelt, H., Sabine, B. K., \& Dormann, C. (2012). Parental role models and the decision to become self-employed: The moderating effect of personality. Small Business Economics 38(1), 121-138. https://doi.org/10.1007/s11187-010-9270-y.

Cox, L. W., Mueller, S. L., \& Moss, S. E. (2002). The Impact of Entrepreneurship Education on Entreprenurial Self-efficacy. International Journal Entrepreneurship Education, 1(2) 229-245.

Díaz-García , M. C., \& Jiménez-Moreno, J. (2010). Entrepreneurial intention: the role of gender. Interntional Journal of Entrepreneurship Management, 6 (3), 261-283. https://doi.10.1007/s11365-008-0103-2

Fatimah, S. (2018, March 1). 1,5 Juta Siswa vocational Akan Lulus, Lapangan Pekerjaan Masih Minim. Retrieved from Okezone.com: https://news.okezone.com/read/2018/03/01/65/1866500/1-5-juta-siswa-vocational-akan-lulus-lapanganpekerjaan-masih-minim

Farrukh, M., Khan, A. A., Khan, M. S., Ramzani, S. R., \& Akeem, B. S. (2017, August 16). Entrepreneurial intentions: the role of familial factors, personality traits and self-efficacy. World Journal of Entrepreneurship, Management and Sustainable Development, 13(4), 303-317. https://doi.org/10.1108/WJEMSD-03-2017-0018

Foster, B. (2018). An investigation on entrepreneurial competencies of creative industry in Bandung, Indonesia. International Journal of Research in Business and Scoail Science, 7(3), 10-17. https://doi:10.20525/ijrbs.v7i3.869

Gibcus, P. (March, 2012). Effects and impact of entrepreneurship programmes in higher education. Brussels: Entrepreneurship Unit Directorate-General for Enterprise and Industry European Commission.

Gupta, V. K., Turban, D. B., Wasti, S. A., \& Sikdar, A. (2017). The role of gender stereotypes in perceptions of entrepreneurs and intentions to become an entrepreneu. Entrepreneurship Theory and Practice, 33(2) 397-417. https://doi.org/10.1111/j.15406520.2009.00296.x

Inibaru.Id, (2018, January 23). Dari Kota Kecamatan ke Pasar Internasional. Retrieved from Bordir Kawalu, https://www.inibaru.id/pasar-kreatif/bordir-kawalu-beken-di-pasarinternasional.

Jennings, W. \& McDougald, M. (2007). Work-family interface experiences and coping strategies: Implications for entrepreneurship research and practice. Academy Management Review, 32(3), 747-760. https://doi: 10.2307/20159332

Joensuu-Salo, S., Varamäki, E., \& Viljamaa, A. (2015). Beyond intentions - what makes a student start a firm? Education + Training, 57(8/9), 853-873. https://doi: 10.1108/ET-11-2014-0142

Jun, T. B., Qian, S., Miao, C., \& James, O. F. (2014). The relationship between entrepreneurship Education and entrepreneurial Intentions: A meta-analytic review. Entrepreneurship Theory and Practice, 38(2), $217-254$. https://doi.org/10.1111/etap.12095

Karimi, S., Chizari, M., Biesman, H. J., Lans, T., \& Mulder, M. (2014). Effects of role models and gender on students' entrepreneurial intentions. European Journal of Training and Development, 38(8), 694-727. https://doi: 10.1108/EJTD-03-2013-0036

Khumaini, A. (2018, December 17). Jabar Teken Kesepakatan Bersama dengan Bukalapak. Retrieved from www.merdeka.com: https://www.merdeka.com/peristiwa/jabar-teken-kesepakatan-bersama-dengan-bukalapak.html

Kok, W. (2004) .Kok Report. report of an independent high-level expert group, headed by formed Dutch Prime Minister Wim Kok, presented to European Commission and the European Council, November 2004.

Kominfo. (2017, March 24). Peluang Besar Jadi Pengusaha Di Era Digital. Retrieved from https://kominfo.go.id/content/detail/9503/peluang-besar-jadi-pengusaha-di-era-digital/0/berita

Konig, A., Kammelander, N., \& Enders, A. (2013). The family innovator's dilemma: How family influence affects the adoption of discontinuous technologies by incumbent firms. Academy of Management Review, 38(3), 418-441. https://doi.org/10.5465/amr.2011.0162 
Kondisi Ekonomi Kota Tasikmalaya (2018). Retrieved from portal.tasikmalayakota.go.id: https://portal.tasikmalayakota.go.id/wpcontent/uploads/2018/02/ekonomi.

Langowitz, M., \& Minniti, M. (2007). The entrepreneurial propensity of women entrepreneurship. Theory and Practice, 31(3), 341364. https://doi.org/10.1111/j.1540-6520.2007.00177.x

Lee, L., Wong, P. K., Foo, M. D., \& Leung, A. (2011). Entrepreneurial intentions: The influence of organizational and individual factor. Journal of Business Venturing, 26(1), 124-136. https://doi.org/10.1016/j.jbusvent.2009.04.003

Lespita, S., Heblich, S., Breugst, N., \& Patzelt, H. (2012). Intergenerational transmission of entrepreneurial intentions. Journal of Business Venturing, 27(4), 414-435. https://doi.org/10.1016/j.jbusvent.2011.11.006

Neequaye, E. N., Dechun, H., Sholihah, P. I., \& Fynn, S. (2017, 11 November). The importance of entrepreneurship in China and Indonesia. European Journal of Business and Management, 9(11), 160-164.

Nitu-Antonie, E. S. (2017). Connecting gender identity, entrepreneurial training, role models and intentions. International Journal of Gender and Entrepreneurship, 9(1), 87-108. https://doi.org/10.1108/IJGE-08-2016-0028

Pant, K. S. (2015). Role of The Family in Entrepreneurship Development in Nepali Society. The Journal of Nepalese Business Studies, 4(1), 37-47. https://doi.org/10.3126/jnbs.v9i1.14592

Sánchez, J. C., \& Licciardello, O. (2012). Gender Differences and Attitudes in Entrepreneurial Intentions: The Role of Career Choice. Journal of Women's Entrepreneurship and Education, 1-2, 7-27.

Schmitt-Rodermund, E., \& Vondracek, F. W. (2002). Occupational dreams, choices and aspirations: Adolescents' entrepreneurial prospects and orientations. Journal of Adolescence, 25(1), 65-78. https://doi: 10.1006/jado.2001.0449

Sequeira, J., Mueller, S. L., \& McGee, J. E. (2007). The effects of attitudes and perceived environment conditions on students' entrepreneurial intent: An Austrian perspective. Education \& Training, 5(4), $272-291$. http://dx.doi.org/10.1108/00400910910964566

Shen, T., Arturo, E. O., \& A. S. (2017). Does family support matter? The influence of support factors on entrepreneurial attitudes and intention. Academy of Entrepreneurship Journal, 23(1), 24-43.

Shinnar, R. S., Hsu, D. K., \& Powell, B. C. (2014). Self-efficacy, entrepreneurial intentions, and gender: Assessing the impact of entrepreneurship education longitudinally. The International Journal of Management Education, 12(3), 561-570.

Shirokova, G., Osiyevskyy, O., \& Bogatyreva, K. (2015). Exploring the intention-behavior link in student entrepreneurship: Moderating effects of individual and environmental characteristics. European Management Journal, 34(4), 386-399. https://doi.org/10.1016/j.emj.2015.12.007

State Minister for Cooperatives Small and Medium Enterprises Indonesia. (2017, March 11). Ratio Wirausaha Indonesia Naik Jadi 31. Retrieved from http://www.depkop.go.id/content/read/ratio-wirausaha-indonesia-naik-jadi-31-persen/

Sugiyono. (2014). Metode Penelitian Pendidikan Pendekatan Kuantitatif, Kualitatif Dan R\&D. Bandung: Alfabeta.

Sulaksono, H. (2018, April 16). Jumalah Pengangguran di Kota Tasikmalaya mencapai 6.8\%. Retrieved from ayotasik.com Web site http://ayotasik.com/read/20180416/122/1236/

Supranto. 2001. Statistik Teori dan Aplikasi. Edisi 6. Jakarta: Erlangga University.

Tarekegne, W.M. \& Gelaneh, A.H. (2019). The integration of entrepreneurship education into Ethiopian universities formal curriculum. International Journal of Research in Business and Social Science, 8(2), 61-73. https://doi:10.20525/ijrbs.v8i2.191

Vaizler, B. (2011). The Impact of Entrepreneurship Education on Entrepreneurial Self-efficacy and Behavior: Unfolding the Effects of Passion and Inspiration (MSc thesis). Haifa, Israel: Technion.

Wijaya, T. (2009). Research Methods for Business Students, 5th Edition. Essex: Pearson Education

Welter, F., Smallbone, D., Isakova, N., \& Aculai, E. (forthcoming). The role of gender for entrepreneurship in a transition context. In L. Iandoli, M. Raffa, \& H. Landström (Eds.), Frontiers in European Research. Elgar: Cheltenham, U.K. and Northampton, MA.

Wyrwich, M. (2015). Entrepreneurship and the Intergenerational Transmission of Values. Small Business Economics, 45(1), 1912013. http://doi 10.1007/s11187-015-9649-x

Yukongdi, V., \& Lopa, N. Z. (2017). Entrepreneurial intention: a study of individual, situational and gender differences. Journal of Small Business and Enterprise Development, 24 (2), 333-352. https://doi: 10.1108/JSBED-10-2016-0168

Zellweger, T., Sieger, P., \& Halter, F. (2010). Should I stay or should I go? Career choice intentions of students with family. Journal of Business Venturing, 26(5), 521-536. https://doi.org/10.1016/j.jbusvent.2010.04.001 